\title{
The adverse effect of real effective exchange rate change on trade balance in European transition countries $^{* 1}$
}

\author{
Selena Begovic ${ }^{2}$, Sead Kreso ${ }^{3}$
}

\begin{abstract}
Most European transition countries have fixed or highly managed flexible exchange rate regimes. This exchange rate rigidity is sometimes argued to worsen the trade balance by keeping the currency overvalued. However, there is no unambiguous evidence that currency depreciation/devaluation positively affects trade balance and leads towards the adjustment, even in the short-run. Therefore, we examine the effect of real effective exchange rate (hereafter REER) on trade balance in European transition economies over the period 2000-2015. By using fixed effect model for static and generalised method of moments for dynamic estimation, we find that there is an adverse effect of the REER on trade balance in European transition countries over the period 2000-2015. Namely, depreciation of REER deteriorates trade balance in European transition countries, which could be explained by high import dependence and low export capacity. This implies that policymakers in European transition countries should not use exchange rate policy to improve trade balance. This is important in the light of their accession towards European economic and monetary integration, implying that these countries should focus more on using fiscal, rather than monetary (and exchange rate), policy to adjust trade balance, which is one of the required real convergence towards the EU standards.
\end{abstract}

Key words: trade balance, real effective exchange rate, European transition countries

JEL classification: F14, F41

\footnotetext{
* Received: 21-08-2017; accepted: 21-12-2017

1 Acknowledgement: We would like to thank anonymous reviewers and editors for their helpful comments and suggestions.

2 Assistant Professor, School of Economics and Business, University of Sarajevo, Trg oslobodjenja 1, 71000 Sarajevo, Bosnia and Herzegovina. Scientific affiliation: monetary policy and international economics. Phone: +38733275 941. E-mail: selena.begovic@efsa.unsa.ba (corresponding author).

${ }^{3}$ Full Professor, School of Economics and Business, University of Sarajevo, Trg oslobodjenja 1, 71000 Sarajevo, Bosnia and Herzegovina. Scientific affiliation: monetary policy, fiscal policy and international economics. Phone:+38733275 918.E-mail: sead.kreso@efsa.unsa.ba.
} 


\section{Introduction}

As European transition countries are mostly small open economies, which rely a lot on export as a source of revenue, the position of trade balance plays an important role in enhancing/deteriorating growth. Bahmani-Oskooee and Kutan (2009) argue that trends in trade balance in these countries are also important for achieving the real economic convergence toward the EU standards. Additionally, movements in trade balance are especially important for countries with rigid monetary regimes since these are the main source of change of monetary base. Therefore, deteriorating trade balances might have even more pronounced contractionary effect on the economies with rigid monetary regimes. Since the changes in the exchange rate can affect trade balances frequently raised question in macroeconomic theory and practice is whether the alteration of the exchange rate could be beneficial for these economies. If there is a long term positive effect of the exchange rate change on trade balance then rigid monetary regimes could be observed as impediments to growth induced by this positive movement of trade balance.

European transition countries mostly have fixed or relatively fixed exchange rate regimes, which are therefore sometimes blamed for inability to adjust trade balance through nominal exchange rate changes. However, even when available, this instrument does not always prove to have the expected effect, especially in the short term (due to delay in reaction of markets on exchange rate change - the phenomenon known as a J-curve) and in particular for import dependent countries. Therefore, prior to deciding whether to alter the exchange rate, it is important to investigate whether there is effect of (real) exchange rate changes on trade balance, and also how (real) exchange rate changes affect countries' competitiveness. Studies which investigate the effect of REER on trade balance found no conclusive results. Bahmani-Oskooee and Kutan (2009) investigated this effect for 11 east European countries individually and find no long-run relationship between real effective exchange rate and the trade balance, while Arize et al. (2017) find that a real depreciation in investigated Asian countries improves the trade balance. Bleaney and Tian (2014) also find trade balance improvement after real depreciation in all investigated 87 countries, with slower adjustment for industrial countries. Falk (2008) investigates cross-country differences between industrialized countries and finds that depreciation of REER index leads to an improvement in trade balance, though in countries with trade balance deficit it is much less sensitive to movements in the REER index. None of the studies investigated the effect of REER for European transition countries specifically. Therefore, this paper aims to fill this gap by estimating this effect in European transition countries, starting from the hypothesis of the adverse effect of REER (that the real depreciation of national currency with respect to trading partner currencies negatively affects trade balance) on trade balance due to import dependence and export limitations in these countries. 
After a short theoretical framework and the literature review in Section 2, methodology for the analysis is presented in Section 3. Based on similar studies, but accounting for sample specifics, the model is specified and empirical analysis presented in Section 4. Section 5 discusses the results, highlights the contribution and limitations of the paper and gives policy recommendations. In the final section the conclusions of the research are drown.

\section{Literature review}

According to international trade theory currency depreciation/devaluation should reduce trade deficit as it makes imports more expensive and exports cheaper. However, import dependence (unavailability of adequate local substitutes) and lack of export capacity and competitiveness could induce an adverse effect of exchange rate depreciation/devaluation on trade balance, especially in the short term (the phenomenon known as J-curve). Namely, if price elasticities are low, the effect of the real exchange rate changes is likely to be adverse: if domestic demand is inelastic to increase in import prices (due to unavailability of adequate substitute) and/or foreign demand (the demand of trading partners of the observed country) is inelastic towards the decrease in prices of goods/services that are exported from the observed country and/or the observed country has low supply elasticity, meaning that even though the demand for the exported goods/services is increased due to lower export prices, there is no enough capacity in the country to satisfy that increased demand. If these inelasticities are present, the country's trade balance will not benefit from the REER depreciation since it would import the same amount but at higher prices and export the same amount at lower prices. McKinnon (1963) argues that exchange rate changes in a relatively open economy are not likely to result in increased competitiveness as the expected positive effect of exchange rate depreciation on exports is likely to be offset by increase in costs and consequently domestic wages and prices. This is especially the case for small price-taker economies. This argument is also supported in subsequent studies (Sepp and Randveer, 2002; Davies and Green, 2010). In the long term it is expected that the exchange rate change will adjust trade balance, even though in the very long run the effect should be neutral since only increased productivity can lead towards the trade adjustment. However, these short and long runs could not be precisely specified and generalised and differ between countries.

Though fixed exchange rate regimes are sometimes "accused" for inability of current account adjustment there is no unambiguous empirical evidence which supports this statement. Some studies find no empirical evidence about the difference in the effect of exchange rate regime on trade/current account balance (Berka et al., 2012; Chinn and Wei, 2013). Other studies find that exchange rate flexibility significantly affects external adjustment (Herrmann, 2009; Ghosh et al., 
2013). Based on these mixed empirical implications, Ghosh et al. (2014) conclude that 'the profession is far from a consensus on the role of flexible exchange rates in facilitating external adjustment'. These ambiguous results might be caused by the fact that even when the exchange rate regime is fixed adjustment of trade balance could be achieved through changes in the prices and productivity. Additionally, currency still fluctuates against other currencies which could also contribute the adjustment process. Therefore, to account for these effects some studies assess the effect of real effective exchange rate (REER) on trade balance.

Most of the empirical studies which investigate the effect of REER on trade balance focus on individual countries. Findings from these studies are also inconclusive. Senadheera (2015) finds no long-run relationship between real effective exchange rate and the trade balance, while he finds an adverse effect of nominal effective exchange rate on trade balance. Namely, according to their results, depreciation of nominal effective exchange rate lead to a deterioration of the trade balance in the long run in Sri Lanka. Stucka (2004) estimated the effect of permanent domestic currency depreciation on trade balance in Croatia. He finds the evidence of the J-curve in Croatia and, even though he finds some evidence of the positive effect of currency depreciation on trade balance, he concluded that it is questionable whether permanent depreciation is desirable to improve the trade balance, taking into account potential adverse effects on the rest of the economy. Petrovic and Gligoric (2010) also find that exchange rate depreciation in Serbia improves trade balance in the long run, while giving rise to a J-curve effect in the short run. Arize et al. (2017) examines the impact of real effective exchange rate on trade balance in eight Asian countries. His results suggest that, in the long run, a real depreciation in these countries improves the trade balance, but imply that the currency depreciation or devaluation can be successful over the long term only if the authorities are willing and able to accompany the exchange-rate policy with other appropriate policies to halt the process that started the trade imbalance. Bahmani-Oskooee and Kutan (2009) investigate the effect of REER on trade balance in 11 east European emerging economies, most of which are the new EU members or the candidate countries, for the period 1990-2004. Their results indicate that there is no long run effect of these countries' currency real depreciation on trade balance and they make a policy implication that policymakers in these countries may not use exchange rate policy for trade balancing and enhancing economic growth. They also suggest that reduction of exchange rate fluctuation is likely to be beneficial for these countries on their way to the Eurozone. However, their analysis is conducted for each country separately.

There are few studies which use panel data in order to investigate differences between the effects of exchange rate on trade balance across countries of different types. Allen (2006) examines the impact of nominal exchange rate movements on the trade balance in a panel of 46 (mostly) middle-income and emerging market countries over the period 1980-2005. He notes that the response of a country's 
trade balance depends crucially on the market structure of its exports; whether it primarily exports goods for which there is highly elastic demand at a given world price, or differentiated products with downward sloping demand curves. Nicita (2013) investigates the importance of exchange rates on international trade by analysing the impact that exchange rate volatility and misalignment have on trade and then by exploring whether exchange rate misalignments affect governments' decisions regarding trade policies on a sample of 100 countries. Their findings suggest the importance of exchange rate misalignment while disregarding that of exchange rate volatility. However, in their literature review Auboin and Ruta (2011), after consulting a large literature on the same issue, conclude that on average, exchange rate volatility has a negative impact on trade flows, but that the extent of this effect depends on a number of factors (such as hedging instruments, the structure of production and the degree of economic integration across countries). Regarding the exchange rate misalignments, the empirical results analysed in Auboin and Ruta (2011) mostly confirm that short-run effects can exist, but their size and persistence over time are not consistent across different studies and the impact again depends on number of features. Bleaney and Tian (2014) use a large dataset of 87 countries to investigate differences between three country groups: industrial, developing and emerging. Their findings suggest trade balance improvement after real depreciation in all countries, with slower adjustment for industrial countries. Falk (2008) investigates crosscountry differences between industrialized countries. He finds that depreciation of REER index leads to an improvement in trade balance, though in countries with trade balance deficit it is much less sensitive to movements in the REER index. However, there is no study which estimates the effect of REER on trade balance in European transition countries. Our analysis considers European transition countries which differ in the level of development as well as exchange rate regimes used. This allows us to estimate the effect of REER on trade balance under different exchange rate regimes and socio-economic circumstances. However, the common characteristics of these counties are the transition process towards the market economy (though the countries are at different stages of transition) and their orientation towards European integration, which will be discussed in more details in Section 4.

\section{Methodology}

To estimate the effect of different determinants on trade balance, first static fixed effect model has been used as it allows to control for countries' specifics not included in the model. Fixed effect model is usually applied for trade balance equation in multi-country empirical analysis (Falk, 2008; Bleaney and Tian, 2014). Falk (2008) derives the trade balance equation from theoretical model introduced by Goldstein and Khan (1985). He includes logarithm of real effective exchange rate, weighted average real GDP per capita of the 40 major trading partners, real domestic GDP per capita, the primary (fiscal) balance as a percentage of GDP 
and controls for country effects. Bahmani-Oskooe and Kutan (2009) control for the same variables as Falk (2008) except fiscal balance. Bleaney and Tian (2014) control for log-changes of REER, terms of trade, GDP growth, country and time fixed effects. Additionally, the control for the foreign direct investment (as a percentage of GDP), labour productivity and EU and EMU membership has been conducted. Rationale for inclusion of each variable and the expected results of the included variables will be further explained. Following the above, the model is specified in Equation 1:

$$
\begin{aligned}
& \ln X M_{i t}=\alpha_{i}+\alpha_{1} \operatorname{lnREER}_{i t}+\left(\beta_{1} \operatorname{lnREER}_{i t-1}+\beta_{2} \operatorname{lnREER}_{i t-2}\right)+ \\
& +\alpha_{2} G D P p c_{i t}+\alpha_{3} \operatorname{GDPg}_{i t}+\alpha_{4} \ln T O T_{i t}+\alpha_{5} G C_{i t}+\alpha_{6} E U_{i t}+ \\
& +\alpha_{7} E M U_{i t}+\alpha_{8} L A B P R O_{i t}+\alpha_{9} F D I_{i t}+\gamma X_{i t}+\delta D_{i t}+\varepsilon_{i t}
\end{aligned}
$$

where XM is a trade balance (measures used for this variable are explained below), REER is real effective exchange rate (contemporaneous and lagged values), GDPpc is real GDP per capita, GDPg is real GDP growth, GC is government consumption as a percentage of GDP, ToT is terms of trade, EU and EMU are dummy variables which are one for EU (EMU) member states (in years when they were member states), LABPRO is labour productivity measured as output per employed person, FDI is foreign direct investment, measured as a percentage of FDI inflow of GDP, $\mathrm{X}$ is country fixed effect and D time fixed effects. eit is the error term assumed to be identically and independently distributed with a zero mean and constant variance. Since it is assumed that any change in other countries' level of income which could affect trade balance would be reflected in real effective exchange rate, the control for trading partners' GDP per capita is not applicable. In order to account for difference in the level of labour productivity, which should be one of the major determinants of trade competitiveness, other than those already accounted for by differences in prices captured by REER, the control for labour productivity has been included. Additionally, this research includes EU and EMU variables since, after becoming EU members, countries have different trade policy and after joining the monetary union they lose any option to alter the nominal exchange rate individually. Subsequently, in this research the lagged values of REER have been added to test for longer term effect in static model, as suggested by Bleaney and Tian (2014).

However, since it can be assumed that the last year's trade balance has an effect on this year's trade balance, the dynamics in this model has been included as to estimate the model (Equation 2) by using generalised method of moments (GMM).

$$
\begin{aligned}
& \ln X M_{i t}=\alpha_{i}+\beta_{1} \ln X M_{i t-1}+\alpha_{1} \operatorname{lnREER}_{i t}+\alpha_{2} G D P p c_{i t}+\alpha_{3} G D P g_{i t}+ \\
& +\alpha_{4} \ln T O T_{i t}+\alpha_{5} G C_{i t}+\alpha_{6} E U_{i t}+\alpha_{7} E M U_{i t}+\alpha_{8} L A B P R O_{i t}+ \\
& +\alpha_{9} F D I_{i t}+\gamma X_{i t}+\delta D_{i t}+\varepsilon_{i t}
\end{aligned}
$$

Test for serial correlation will also be used as an indication of need for including dynamics in the model. All GMM techniques for estimating dynamic panel models 
are argued to be suitable for panels with wide cross section $(\mathrm{N})$ and short time series (T). Other advantages of the GMM are that distributional assumptions, such as normality, are not required and that it enables us to control for unobserved heterogeneity of the same countries over time (Verbeek, 2004). The ArellanoBover/Blundell-Bond (so called 'system' GMM) builds a system of two equations: a difference equation which is instrumented by levels; and a levels equation instrumented by first differences. 'System' GMM is more comprehensive than 'difference' $\mathrm{GMM}^{4}$, since lagged levels (used in 'difference' GMM) are argued to be rather poor instruments for first differenced variables, especially for variables that are close to a random walk, which is frequently the case with macroeconomic variables (Baum, 2006). Additionally, GMM allows us to treat some variables as endogenous (this will be specified in the next section). More specific issues regarding the methodology are discussed in the next section with the results.

\section{Empirical data and analysis}

The analysis includes all European transition countries (determined as transition countries by European Bank for Reconstruction and Development), except Kosovo and Montenegro due to data limitation. However, 17 countries included in the analysis could be divided in subgroups based on their size, level of development, geographical position and progress toward European integration. Some of the countries from the sample are already members of European Union (Bulgaria, Croatia, Cyprus, Estonia, Greece, Hungary, Latvia, Lithuania, Poland, Romania, Slovakia and Slovenia), some of which are already European monetary union members (Cyprus, Estonia, Greece, Lithuania and Slovenia). Others are in the process of accession in the EU (Albania, Bosnia and Herzegovina, Macedonia, Serbia and Turkey). Therefore, the empirical analysis has been done to control for these differences. Regarding the exchange rate regime in the countries from the sample it does not differ much during the observed period. Countries mostly fixed their currencies against euro ${ }^{5}$, except Turkey, which had freely floating regime from 2001 until 2003 and then managed floating/de facto moving band against the US dollar (Ilzetski et al., 2017).

\footnotetext{
$\overline{4}$ The Arellano-Bond approach (the so called 'difference' GMM), which uses lagged values of the levels as instruments for the equations in first differences, is not conducted since it drops out the variable of interest, which is time-invariant.

5 Most of the countries in the sample have had de facto peg exchange rate regime (pegged to euro) during the period observed (Albania, since 2014; Cyprus until 2008; Croatia; Latvia since 2004 until 2014; Macedonia; Romania since 2012; Slovenia until 2007), currency board arrangement (currency fixed to euro) (Bosnia and Herzegovina, Bulgaria, Estonia until 2011 and Lithuania until 2015) and some de facto crawling peg around euro (Albania until 2009; Hungary; Latvia until 2004; Poland; Romania, until 2012; Serbia and Slovak, until 2009). However, their currencies did not fluctuate more than $+-15 \%$ from the euro, which is within the allowed oscillation for the Exchange rate mechanism II) in the observed period (for details see de facto classification by Ilzetski et al., 2017).
} 
After conducting the analysis for the sample of 17 countries, the focus has been put on 6 economies which belong to the same (Balkan) region and which are among the least developed European transition countries (see Figure 1). These countries are Albania, Bosnia and Herzegovina, Bulgaria, Croatia, Macedonia and Serbia. The estimation of this subsample serves as a robustness check and these countries are chosen given that they belong to the same region and are at more similar level of development.

Figure 1: GDP per capita (in US dollars) in sample countries

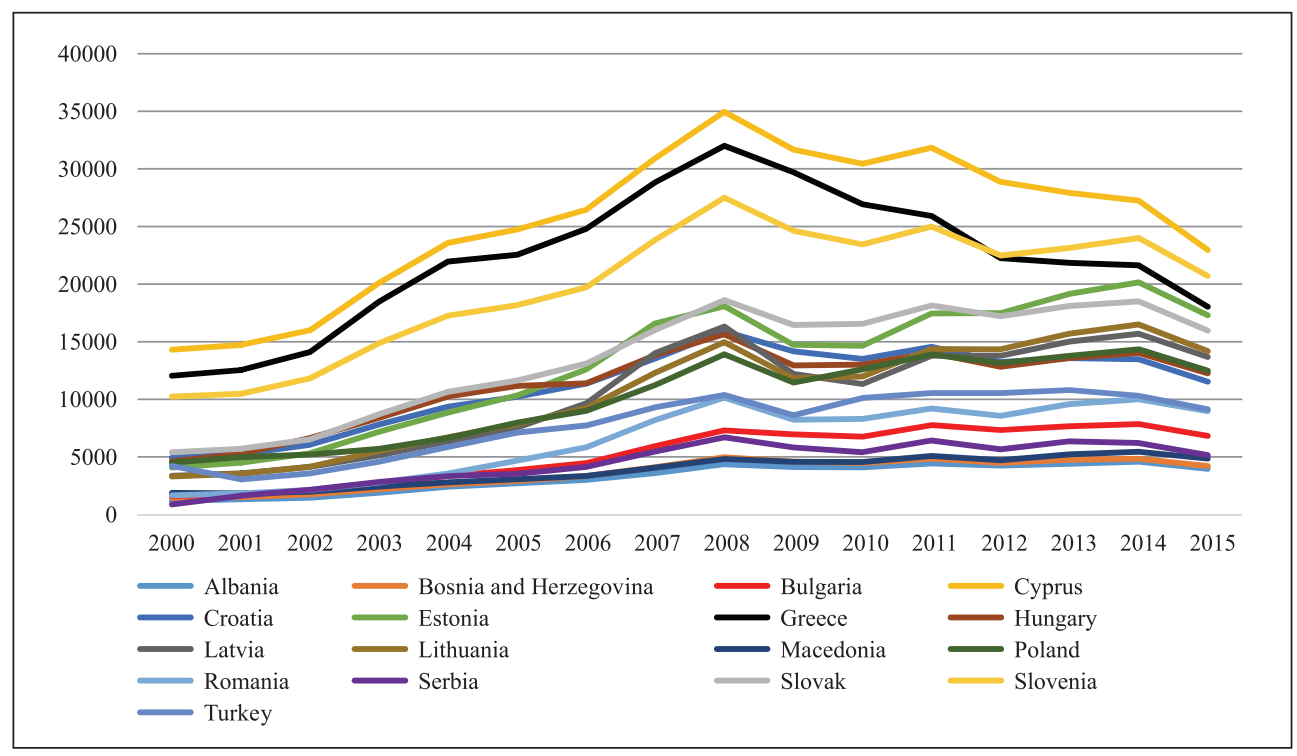

Source: Authors illustration based on the data from World development indicator database

There are different measures of trade balance used in studies: difference between export and import weighted by total value of trade (Bleaney and Tian, 2014), difference between exports and imports as a ratio of nominal GDP (Falk, 2008) and log exports to imports ratio (Bahmani-Oskooee and Kutan, 2009) - the last measure is also suggested as an alternative measure by Falk (2008) and Bleaney and Tian (2014). In our analysis the export - import ratio (X/M) has been used. In order not to neglect the fact that trade balance can improve at the expense of decreased openness, which is not beneficial for a country, the export import ratio has been weighted by trade openness (calculated as a sum of values of exports and imports as a percentage of GDP) (X/M*Open), which was not done in previous studies. Next, the rationale and expected effect of independent variables are discussed and descriptive statistics presented.

The decline in the REER reflects the reduction in cost of producing domestic goods due to depreciation/devaluation of domestic currency to currency of 
trading partners and/or due to beneficial inflation difference in domestic economy compared to those in trading partners' economies. This should consequently increase export competitiveness and positively affect trade balance, although, as noted in Section 2, this effect might be adverse due to import dependence and/or lack of export capacity, which could be the case in our sample since the observed countries are transition, mostly import dependent, countries. This research includes GDP per capita to control for differences in the level of development between countries and it has been expected that richer countries would spend more on imports, therefore deteriorating trade balance. The same logic lies behind the expected effect of GDP growth variable. Furthermore, the government consumption is expected to have negative effect on trade balance as expenditure of public sector might be discouraging for the private export sector. This is especially the case for countries in transition that are usually faced with high level of so called unproductive consumption, not directed for development but could crowd out private investments, some of which are export oriented and/or substitute import oriented. We expect positive sign on labour productivity since higher productivity should make export goods more competitive and therefore increase trade surplus/ decrease trade deficit. Higher FDI inflows should negatively affect trade balance since additional resources are brought to the countries and are expected to increase consumption, part of which is the consumption of import goods. In Table 1 summary statistics for included variables is presented. Data for all variables except REER, FDI and labour productivity are from World Development Indicator database. The data for REER and FDI are from UNCTAD database. Data for labour productivity is from Total economy database. There are some missing values ${ }^{6}$ and therefore our panel is unbalanced.

Table 1: Summary statistics

\begin{tabular}{|l|c|r|r|r|r|}
\hline \multicolumn{1}{|c|}{ Variable } & OBS. & \multicolumn{1}{c|}{ MEAN } & \multicolumn{1}{c|}{ STD.DEV. } & \multicolumn{1}{c|}{ MIN. } & \multicolumn{1}{c|}{ MAX. } \\
\hline XM & 264 & 84.25259 & 18.21521 & 34.36468 & 113.9678 \\
\hline REER & 218 & 108.1477 & 22.10905 & 80.01384 & 264.9283 \\
\hline GDPG & 272 & 4.422604 & 2.712855 & 0.054558 & 14.81416 \\
\hline GDPPC & 272 & 10695.97 & 7483.314 & 870.1365 & 34950.35 \\
\hline TOT & 247 & 98.53707 & 5.107875 & 86.4448 & 109.517 \\
\hline GC & 265 & 18.04939 & 2.958395 & 9.454983 & 24.50624 \\
\hline LABPRO & 272 & 50754.58 & 15101.23 & 18882.38 & 81475.89 \\
\hline FDI & 263 & 4.615906 & 12.08705 & -78.8232 & 156.4145 \\
\hline
\end{tabular}

Source: Authors' calculations

$\overline{6}$ There is no data for REER for BH, Bulgaria, Cyprus, Lithuania, Romania and Turkey prior 2005 and for Serbia prior 2008. There are also few missing data for other variables. 
As noted in the previous section, fixed effect model is used for estimating the static model. Hausman specification test was performed in Stata and the respective p-value of 0.0000 suggests that the null hypothesis that the random effects estimator is consistent is soundly rejected. This suggests that the fixed effects is the more appropriate than random effects estimator for this estimation. Moreover, fixed effect model allows us to control for country specifics not controlled by variables included in the model. The results of fixed effect estimation are presented in Table 2.

Table 2: The results of Equation 1 estimated with the fixed effect model for the whole sample (number of countries: 17)

\begin{tabular}{|c|c|c|c|}
\hline \multirow{3}{*}{\begin{tabular}{|l|l|l} 
Independent \\
variables
\end{tabular}} & $\mathrm{X} / \mathrm{M}$ & $\mathrm{X} / \mathrm{M}$ & $\mathrm{X} / \mathrm{M}^{*}$ Open \\
\hline & $\begin{array}{l}\text { Only contemporaneous } \\
\text { value of REER }\end{array}$ & \multicolumn{2}{|c|}{$\begin{array}{l}\text { Contemporaneous and lagged } \\
\text { values of REER included }\end{array}$} \\
\hline & $0.0952^{*}$ & $0.118^{* *}$ & $0.102^{*}$ \\
\hline & $(0.0476)$ & $(0.0408)$ & $(0.0549)$ \\
\hline \multirow[t]{2}{*}{ L1LNREER } & & $0.0761^{*}$ & $0.231^{* * * *}$ \\
\hline & & $(0.0419)$ & $(0.0455)$ \\
\hline \multirow[t]{2}{*}{ L2LNREER } & & $-0.0964^{*}$ & -0.00359 \\
\hline & & $(0.0463)$ & $(0.0772)$ \\
\hline \multirow[t]{2}{*}{ GDPG } & -0.00334 & $-0.00582^{*}$ & $-0.00947^{* *}$ \\
\hline & $(0.00272)$ & $(0.00314)$ & $(0.00352)$ \\
\hline \multirow[t]{2}{*}{ GDPPC } & $-1.63 e-05^{* *}$ & $-2.10 \mathrm{e}-05^{* *}$ & $-2.19 \mathrm{e}-05^{*}$ \\
\hline & $(7.02 \mathrm{e}-06)$ & $(7.35 e-06)$ & $(1.10 \mathrm{e}-05)$ \\
\hline \multirow[t]{2}{*}{ LNTOT } & $0.685^{* *}$ & $0.688^{*}$ & 0.307 \\
\hline & $(0.302)$ & $(0.373)$ & $(0.626)$ \\
\hline \multirow[t]{2}{*}{$\mathrm{GC}$} & -0.00386 & -0.00991 & $-0.0265^{* *}$ \\
\hline & $(0.00955)$ & $(0.0109)$ & $(0.0116)$ \\
\hline \multirow[t]{2}{*}{$\mathrm{EU}$} & -0.0468 & -0.0454 & -0.0663 \\
\hline & $(0.0361)$ & $(0.0348)$ & $(0.0390)$ \\
\hline \multirow[t]{2}{*}{ EMU } & -0.0203 & -0.0273 & -0.0447 \\
\hline & $(0.0355)$ & $(0.0344)$ & $(0.0632)$ \\
\hline \multirow[t]{2}{*}{ LABPRO } & $3.73 e-06$ & $3.11 \mathrm{e}-06$ & $4.58 \mathrm{e}-06$ \\
\hline & $(3.03 \mathrm{e}-06)$ & $(3.86 \mathrm{e}-06)$ & $(5.38 \mathrm{e}-06)$ \\
\hline \multirow[t]{2}{*}{ FDI } & $-0.000384^{* *}$ & $-0.000419^{* * * *}$ & $7.35 \mathrm{e}-05$ \\
\hline & $(0.000135)$ & $(0.000130)$ & $(0.000117)$ \\
\hline Time dummies & included & included & included \\
\hline Observations & 217 & 183 & 183 \\
\hline R-squared & 0.679 & 0.750 & 0.866 \\
\hline
\end{tabular}

Note: ***,**,* donate the significance level of $1 \%, 5 \%$ and $10 \%$ respectively. Robust standard errors are reported in the parenthesis. Most of the time dummies are significant, but not presented here due to space limitations. ${ }^{7}$

Source: Authors' calculations

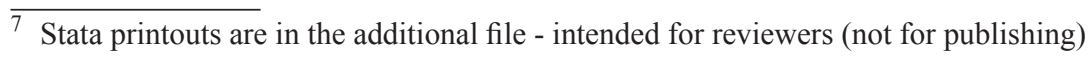


As noted in the previous section, in the first estimation (results in the second column) the coverage of imports by exports is used as the dependent variable and only contemporaneous values of REER are used. In the second estimation the same measure for the dependent variable is used, but lagged values of REER are also included in the model (the results in the third column). In the third estimation, exportimport ratio is weighted by openness (the dependent variable) and again lagged and contemporaneous values of REER are controlled for (the results in the fourth column).

According to the static analysis the real effective exchange rate appreciation improves trade balance in European transition countries over the period 20002015. The first lag of REER is also significant and positive while the second leg is significant and negative (when XM is used as the dependent variable) and insignificant (when XM*openness is used as the dependent variable). This could be explained by high import dependence of European transition countries, especially in the short term. However, these results should be taken with a caution since autocorrelation is present and should be treated by introducing dynamics in the model. Therefore, the model using GMM and treating REER as endogenous has been estimated next, since it has been assumed that decline in trade deficit is likely to put a pressure on demand for domestic currency, consequently increasing REER. The results of dynamic estimation (Equation 2) are presented in Table 3.

Table 3: The results of Equation 2 estimated by GMM for the whole sample (number of countries: 17)

\begin{tabular}{|l|r|r|}
\hline Dependent variable & \multicolumn{1}{|c|}{ X/M } & \multicolumn{1}{c|}{ X/M*Open } \\
\hline Independent variables & $0.879^{* * *}$ & $0.923^{* * *}$ \\
\hline L.LNXM_OPEN & $(0.0540)$ & $(0.0294)$ \\
\hline & & $0.214^{* * *}$ \\
\hline LNREER & & $(0.0548)$ \\
\hline & $0.101^{* * *}$ & $-1.26 \mathrm{e}-06$ \\
\hline GDPPC & $(0.0355)$ & $(2.93 \mathrm{e}-06)$ \\
\hline & $9.21 \mathrm{e}-08$ & -0.00294 \\
\hline GDPG & $(3.24 \mathrm{e}-06)$ & $(0.00428)$ \\
\hline & -0.000832 & -0.205 \\
\hline LNTOT & $(0.00301)$ & $(0.140)$ \\
\hline & 0.0600 & 0.00315 \\
\hline GC & $(0.112)$ & $(0.00253)$ \\
\hline & 0.00144 & $0.0728^{* * *}$ \\
\hline EU & $(0.00112)$ & $(0.0253)$ \\
\hline & 0.0275 & -0.0338 \\
\hline EMU & $(0.0208)$ & -0.0253 \\
\hline
\end{tabular}


Selena Begović, Sead Kreso $\bullet$ The adverse effect of real effective exchange rate change... Zb. rad. Ekon. fak. Rij. • $2017 \cdot$ vol. $35 \cdot$ no. $2 \cdot 277-299$

\begin{tabular}{|l|r|r|}
\hline \multicolumn{1}{|c|}{ Dependent variable } & \multicolumn{1}{|c|}{ X/M } & \multicolumn{1}{c|}{ X/M*Open } \\
\hline Independent variables & $(0.0553)$ & $(0.0381)$ \\
\hline LABPRO & $6.93 \mathrm{e}-07$ & $-1.09 \mathrm{e}-07$ \\
\hline & $(8.71 \mathrm{e}-07)$ & $(1.11 \mathrm{e}-06)$ \\
\hline FDI & $-0.000513^{* * *}$ & $-0.000461^{* * *}$ \\
\hline & $(0.000119)$ & $(0.000127)$ \\
\hline Time dummies & included & included \\
\hline Observations & 208 & 208 \\
\hline
\end{tabular}

Note: $* * *, * *, *$ donate the significance level of $1 \%, 5 \%$ and $10 \%$ respectively. Robust standard errors are reported in the parenthesis. Most of the time dummies are significant, but not presented here due to space limitations.

Source: Authors' calculations

Highly significant and positive lagged dependent variable (L.LNXM and L.LNXM OPEN) implies that previous trends in trade balance affect current trends and that dynamic model is more appropriate for the estimation of this model. Moreover, the size of the coefficient on the lagged dependent variable from the dynamic estimation lies between the estimated values of the coefficients from, respectively, OLS and fixed effect estimation. In spite of our concerns over instrument validity, given the small sample size, this diagnostic check is consistent with the validity of the model (Table 4).

Table 4: Diagnostic tests for the estimation of Equation 2 with GMM

\begin{tabular}{|l|r|r|}
\hline \multicolumn{1}{|c|}{ Dependent variable } & X/M & \multicolumn{1}{c|}{ X/M*Open } \\
\hline Number of observations & 208 & 208 \\
\hline Number of groups & 17 & 17 \\
\hline Number of instruments & 72 & 72 \\
\hline Hansen/Sargan $($ PROB $>$ CHI2) & $1 / 0.001$ & $1 / 0.152$ \\
\hline $\mathrm{m} 1+\mathrm{m} 2(\operatorname{Pr}>\mathrm{z})$ & $0.007 / 0.127$ & $0.002 / 0.107$ \\
\hline
\end{tabular}

Source: Authors' calculations

Due to our small sample, we used the minimum number of lags. However, even with a minimum number of lags we still have more instruments than groups, due to the small sample available, from only 17 countries (the number of instruments for each specification are 72 while the number of groups is 17, as noted in Table 4). Consequently, the Hansen version of the Sargan test is too weak, which is indicated by the $p$-value $=1.00$, meaning that it is unable to reject the null hypothesis of instrument validity (strictly, the validity of the over-identifying instruments). However, the Sargan test is available and suggests that there is no problem with 
instrument validity in the final specification (when export-import ratio weighted by trade openness is used as the dependent variable). Therefore, we should consider these results as most reliable. Moreover, tests for the first $(\mathrm{m} 1)$ and second order autocorrelation $(\mathrm{m} 2)$ suggest no problem with autocorrelation in the difference residuals, which is consistent with instrument validity. The $\mathrm{m} 2+\mathrm{m} 1$ procedure requires rejection of the null of $\mathrm{m} 1$, meaning that there is first-order autocorrelation, and "acceptance" of $\mathrm{m} 2$ null, meaning that there is no second-order autocorrelation; conditions which are satisfied in all specifications. Dynamic model results also imply positive and significant effect of REER on trade balance. Calculation of the long term effect imply the same finding. We also estimated the preferred model with the variable which controls for the differences in the exchange rate regimes (since the regimes are not the same across the countries and period observed) and this variable is not significant. Other results do not change significantly when this variable is added. As noted above, even though the regimes differ all countries tend to fix their currencies to the euro on their way to European (monetary) integration and even those with de facto crawling band vary mostly by $+-5 \%$ (which is lower than required fluctuation in ERM II).

Next, we estimate the model on subsample of 6 Balkan transition countries: Albania, Bosnia and Herzegovina, Bulgaria, Croatia, Macedonia and Serbia. The estimation method is the same as for the large sample (results are reported in Table 5).

Table 5: The results of Equation 1 estimated with the fixed effect model for Balkan countries (number of countries: 6)

\begin{tabular}{|c|c|c|c|}
\hline Dependent & $\mathrm{X} / \mathrm{M}$ & $\mathrm{X} / \mathrm{M}$ & $\mathrm{X} / \mathrm{M}^{*}$ Open \\
\hline $\begin{array}{l}\text { Independent } \\
\text { variables }\end{array}$ & $\begin{array}{l}\text { Only contemporaneous } \\
\text { value of REER }\end{array}$ & \multicolumn{2}{|c|}{$\begin{array}{l}\text { Contemporaneous and lagged } \\
\text { values of REER included }\end{array}$} \\
\hline \multirow[t]{2}{*}{ LNREER } & $0.113^{*}$ & $0.0615^{* *}$ & $0.0716^{*}$ \\
\hline & $(0.0480)$ & $(0.0226)$ & $(0.0340)$ \\
\hline \multirow[t]{2}{*}{ L1LNREER } & & $0.137^{* *}$ & $0.198^{* * *}$ \\
\hline & & $(0.0444)$ & $(0.0388)$ \\
\hline \multirow[t]{2}{*}{ L2LNREER } & & $-0.0942^{* *}$ & 0.0355 \\
\hline & & $(0.0351)$ & $(0.0403)$ \\
\hline \multirow[t]{2}{*}{ GDPG } & -0.000144 & -0.00315 & 0.000401 \\
\hline & $(0.00369)$ & $(0.00671)$ & $(0.00397)$ \\
\hline \multirow[t]{2}{*}{ GDPPC } & $-4.09 \mathrm{e}-07$ & $-2.32 e-05$ & $-1.81 \mathrm{e}-05$ \\
\hline & $(1.53 \mathrm{e}-05)$ & $(1.66 \mathrm{e}-05)$ & $(1.66 \mathrm{e}-05)$ \\
\hline \multirow[t]{2}{*}{ LNTOT } & 0.265 & $0.980^{* * *}$ & $-0.717^{*}$ \\
\hline & $(0.453)$ & $(0.238)$ & $(0.329)$ \\
\hline \multirow[t]{2}{*}{$\mathrm{GC}$} & 0.00294 & $-0.0330^{* *}$ & $-0.0568^{*}$ \\
\hline & $(0.00916)$ & $(0.0107)$ & $(0.0264)$ \\
\hline
\end{tabular}




\begin{tabular}{|c|c|c|c|}
\hline \multirow{2}{*}{ 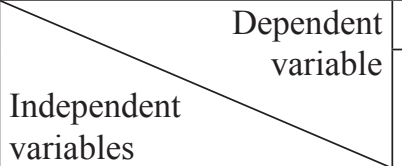 } & $\mathrm{X} / \mathrm{M}$ & $\mathrm{X} / \mathrm{M}$ & $\mathrm{X} / \mathrm{M} *$ Open \\
\hline & $\begin{array}{l}\text { Only contemporaneous } \\
\text { value of REER }\end{array}$ & \multicolumn{2}{|c|}{$\begin{array}{l}\text { Contemporaneous and lagged } \\
\text { values of REER included }\end{array}$} \\
\hline \multirow[t]{2}{*}{$\mathrm{EU}$} & -0.0480 & -0.0545 & -0.0432 \\
\hline & $(0.0318)$ & $(0.0361)$ & $(0.0550)$ \\
\hline \multirow[t]{2}{*}{ LABPRO } & $1.11 \mathrm{e}-05$ & $4.05 \mathrm{e}-06$ & $6.71 \mathrm{e}-06$ \\
\hline & $(6.09 \mathrm{e}-06)$ & $(5.46 \mathrm{e}-06)$ & $(8.23 \mathrm{e}-06)$ \\
\hline \multirow[t]{2}{*}{ FDI } & -0.000208 & $0.00278^{*}$ & 0.00564 \\
\hline & $(0.00302)$ & $(0.00117)$ & $(0.00378)$ \\
\hline Time dummies & included & included & included \\
\hline Observations & 72 & 60 & 60 \\
\hline R-squared & 0.847 & 0.912 & 0.936 \\
\hline
\end{tabular}

Note: $* * *, * *, *$ donate the significance level of $1 \%, 5 \%$ and $10 \%$, respectively. Robust standard errors are reported in the parenthesis. The results of the estimation of fixed effect model conducted in Stata (Stata printouts are available from authors on request).

Source: Authors' calculations

When the small sample is estimated by fixed effect model the test for serial correlation indicates that there is no problem with serial correlation when both contemporaneous and lagged values of REER are included in the model. Robust standard errors are used to control for heteroscedasticity. The results do not change significantly from those of the large sample, which could be used as an additional robustness check. Again, the effect of REER is positive and significant. When lagged values of REER are included the first lag is significant and positive while the second one is significant and negative when export-import ratio is used as the dependent variable and insignificant when this ratio is weighted by the level of openness. TOT variable is significant and positive in specifications in which lagged values of REER are included. Its sign is as expected since improved terms of trade are stimulating countries trade balance. In this sample government consumption is significant and negative also when contemporaneous and lagged values of REER are included, indicating that in these countries high government consumption is likely to be an impediment to export due to crowding out effect of private/export oriented investments by public expenditures. The dynamic estimation also suggests positive effect of REER. However, since the test for the serial correlation does not suggest problem with serial correlation for this sample and since the sample is too small (number of instrument is almost equal to number of observations) we do not report results from dynamic model (the results are presented in the appendix). In the next section, these results will be discussed in relation to previous studies as well as policy recommendations based on the findings in this research. 


\section{Results and discussion}

Movements in trade balance are particularly important since they directly affect countries' GDP. This is especially important for small export-oriented countries, but also for those that rely heavily on imports although they have domestic resources. Since one way to affect trade balance is through changes in the exchange rate, prior to making decision about altering the nominal exchange rate to adjust trade balance the effect of exchange rate changes on trade balance should be investigated. If countries do not have substitutes for imports or cannot increase capacity and competitiveness of exports the expected effect of exchange rate change will be absent. Previous studies which investigate the effect of REER on trade balance found no conclusive results and none of the studies estimate the effect for transition countries. Therefore, this paper aims to fill this gap by estimating this effect in European transition countries.

Since most of the European transition countries have fixed (some are already members of the Eurozone) or highly managed flexible exchange rate regimes the effect of real effective exchange rate, which accounts for relative changes in prices and changes in the exchange rate with all trading partners, is observed. The results of our empirical analysis suggest that the appreciation of real exchange rate improves trade balance (depreciation of REER deteriorates trade balance) in European transition countries, presumably due to high import dependence and lack of export capacity in these countries, which confirms our hypothesis. These results might be considered to be a support for individual analysis conducted for 11 individual European countries by Bahmani-Oskooee and Kutan (2009) in which they conclude that real depreciation is not effective in the long run and that policymakers in the countries they observed may not use exchange rate policy to adjust balance of trade and enhance economic growth. Since depreciation of real effective exchange rate leads to a deterioration of trade balance within our samples, it can be concluded that currency devaluation (where available) is not an effective policy tool to improve these transition countries' trade balance. Davies and Green (2010) provide evidence that changes in import prices as a consequence of a fall in the exchange rate are passed through to domestic prices more rapidly in emerging market economies, which could be used as an additional argument for the adverse effect of exchange rate change on trade balance. Moreover, in transition countries it is important to keep the monetary stability and the alteration of exchange rate for the purpose of stimulating export could disturb this stability (as it is likely that in these countries the political pressures on monetary authority would then increase). Countries should therefore use other policy tools to improve trade balance, by encouraging and supporting production and consumption of domestic goods, as well as increasing productivity in order to make domestic goods more competitive. However, prior to making a policy decision on future actions, the analysis should be conducted for each country separately (after a long enough time series of data 
is available). Moreover, it would be useful to distinguish between import goods for the final consumption and those used as an intermediary goods for products which are being exported (these data were also not available for all countries in our sample). Furthermore, distinction between different industries would provide additional useful information. Therefore, further research should be directed to addressing more specific issues which would provide more explicit evidence for particular policy decisions. The aim of this paper is to give an initial insight into the effect of REER on trade balance in European transition countries and to argue against unsupported propositions regarding the need for higher flexibility of exchange rate regimes for adjusting trade balances in transition countries. In addition to our findings, which suggest that changes in the exchange rate do not necessarily provide the expected effect on trade balance, is the statement that small open economies (which is characteristic for most European transition countries) cannot achieve improvement in real macroeconomic performance through exchange rate flexibility (Schuler, 1996).

\section{Conclusion}

Fixed, or highly managed floating, exchange rate regimes, which are used in most European transition countries, are sometimes argued to worsen the trade balance by keeping the currency overvalued. However, there is no empirical study that investigates this causality for European transition countries. The aim of this paper is to fill this gap by examining the effect of real effective exchange rate (hereafter REER) on trade balance in European transition economies over the period 20002015. By using fixed effect model for static and generalised method of moments for dynamic estimation, in this research it has been found that there is an adverse effect of the REER change on trade balance in European transition countries over the period 2000-2015, which confirms our hypothesis. Namely, depreciation of REER change deteriorates trade balance in European transition countries, which could be explained by high import dependence and low export capacity and competitiveness of transition countries, and by fast transmission of higher import prices into domestic prices. However, due to data limitation for all countries in the sample, this paper does not investigate the reasons behind the adverse effect of REER change on trade balance. Future research should assess which of the above named effects prevail across different countries and different industries. Findings in this paper imply that policymakers in European transition countries should not use exchange rate policy to improve trade balance. This is important in the light of their accession towards European and monetary integration, implying that these countries should focus more on using fiscal, rather than monetary (and exchange rate), policy to adjust trade balance, which is one of the required real convergence towards the EU standards. 


\section{References}

Allen, M. (2006) "Exchange Rates and Trade Balance Adjustment in Emerging Market Economies", IMF working paper.

Arize, A., Malindretos, J., Igwe, E. (2017) "Do Exchange Rate Changes Improve the Trade Balance: An Asymmetric Nonlinear Cointegration Approach", International Review of Economics and Finance Vol. 49, pp. 313-326, doi: 10.1016/j.iref.2017.02.007.

Auboin, M., Ruta, M. (2011) "The Relationship between Exchange Rates and International Trade: A Literature Review", Geneve: WTO, Staff Working Paper, No. 17, doi: 10.2139/ssrn.1955847.

Bahmani-Oskooee, M., Kutan, A. (2009) "The J-curve in the Emerging Economies of Eastern Europe", Applied Economics, Vol. 41, No. 20, pp. 2523-2532, doi: 10.1080/00036840701235696.

Baum, C. (2006) An Introduction to Modern Econometrics Using Stata, A Stata Press Publication, StataCorp LP, College Station, Texas.

Berka, M., Devereux, M., Engel, C. (2012) "Real Exchange Rate Adjustment In and Out of the Eurozone", American Economic Review, Vol. 102, No. 3, pp. 179-85, doi: 10.1257/aer.102.3.179.

Bleaney, M., Tian, M. (2014) "Exchange Rates and Trade Balance Adjustment: A Multi-Country Empirical Analysis”, Open Economies Review, Vol. 25, No. 4, pp. 655-675, doi: 10.1007/s11079-014-9310-3.

Chinn, M., Wei, J. (2013) "A Faith-based Initiative Meets the Evidence: Does a Flexible Exchange Rate Regime Really Facilitate Current Account Adjustment?", Review of Economics and Statistics, Vol. 95, No. 1, pp. 168-184, doi: 10.1162/REST_a_00244.

Davies, H., Green, D. (2010) Banking on the Future: The Fall and Rise of Central Banking, Princeton University Press, doi: http://www.jstor.org/stable/j.ctt7tbpj.

Falk, M. (2008) "Determinants of the Trade Balance in Industrialized Countries", FIW Research Report, No. 013.

Herrmann, S. (2009) "Do We Really Know That Flexible Exchange Rates Facilitate Current Account Adjustment? Some New Empirical Evidence for CEE Countries", Applied Economics Quarterly, Vol. 55, No. 4, pp. 295-311, doi: 10.3790/aeq.55.4.295.

Ghosh, A., Qureshi, M., Tsangarides, C. (2013) "Is the Exchange Rate Regime Really Irrelevant for External Adjustment?", Economics Letters, Vol. 118, No. 1, pp. 104-109, doi: 10.1016/j.econlet.2012.09.010.

Ghosh, A., Qureshi, M., Tsangarides, C. (2014) "The Cost of Tying One's Hands", Finance \& Development, Vol. 51, No. 2, pp. 42-46. 
Ilzetski, E., Reinhart, C., Rogoff, K. (2017) “The Country Chronologies to Exchange Rate Arrangements into the 21 st Century: will the anchor currency hold?", NBER working paper series No. 23135, doi: 10.3386/w23135.

McKinnon, R. (1963) “Optimum Currency Area”, The American Economic Review, Vol. 53, No. 4, pp. 717-725, http://www.jstor.org/stable/1811021.

Nicita, A. (2013) "Exchange Rates, International Trade and Trade Policies", International Economics, Vol. 135-136, pp. 47-61, doi: 10.1016/j.inteco.2013.10.003.

Petrovic, P. and Gligoric, M. (2010) "Exchange Rate and Trade Balance: J-curve Effect”, Panoeconomicus, No. 1, pp. 23-41, doi: 10.2298/PAN1001023P.

Schuler, K. (1996) Should Developing Countries Have Central Banks? Currency Quality and Monetary Systems in 155 Countries (Research Monograph), Institute of Economic Affairs.

Senadheera, Y. (2015) "Impact of the Effective Exchange Rate on the Trade Balance of Sri Lanka: Evidence from 2000 to 2013", Margin - The Journal of Applied Economic Research, Vol. 9, No. 2, pp. 93-108, doi: 10.1177/0973801014568146.

Sepp, U., Randveer, M. (2002) "A Currency Board Arrangement versus Alternative Exchange Rate Regimes in Estonia”. In: Sepp, U., Randveer, M. (eds.) Alternative Monetary Regimes in Entry to EMU, Tallinn: Bank of Estonia.

Stucka. T. (2004) "The Effects of Exchange Rate Change on the Trade Balance in Croatia", IMF Working Paper, No. 65, doi: 10.5089/9781451848717.001.

Verbeek, M. (2004) A Guide to Modern Econometrics, John Wiley \& Sons, Ltd. 


\title{
Nepovoljan efekt promjena realnog efektivnog tečaja na trgovinsku bilancu u Europskim tranzicijskim zemljama
}

\author{
Selena Begović ${ }^{1}$, Sead Kreso ${ }^{2}$
}

\begin{abstract}
Sažetak
Većina Europskih tranzicijskih zemalja koristi fiksni ili čvrsto vođen fleksibilni tečaj. Ove rigidne režime često optužuju da održavanjem precijenjene valute pogoršavaju trgovinsku bilancu. Međutim, ne postoje izravni dokazi da valutna deprecijacijal devalvacija pozitivno utječe na trgovinsku bilancu i da doprinosi prilagođavanju, čak niti kratkoročno. Stoga se u ovom radu ispituje efekt realnog efektivnog tečaja (RET) na trgovinsku bilancu u Europskim tranzicijskim zemljama u periodu 20002015. Primjenom modela fiksnih efekata za statičku analizu i generalizirane metode momenata za dinamičku analizu, rezultati upućuju da je prisutan nepovoljan efekt RET na trgovinsku bilancu u Europskim tranzicijskim zemljama u periodu 20002015. Naime, deprecijacija RET pogoršava trgovinsku bilancu u Europskim tranzicijskim zemljama, što se može objasniti velikom uvoznom ovisnošću i niskim izvoznim kapacitetima. Ovi nalazi impliciraju da kreatori politike u Europskim tranzicijskim zemljama ne trebaju koristiti politiku tečaja kako bi poboljšali stanje u trgovinskoj bilanci. Ovo je bitno za integraciju ovih zemalja u Europsku ekonomsku i monetarnu uniju i također implicira da se ove zemlje trebaju više usredotočiti na korištenje fiskalne, a ne monetarne (i tečajne), politike kako bi uravnotežili trgovinsku bilancu, da bi zadovoljili jedan od traženih kriterija realne konvergencije ka EU standardima.
\end{abstract}

Ključne riječi: trgovinska bilanca, realni efektivni tečaj, Europske tranzicijske zemlje

JEL klasifikacija: F14, F41

${ }_{1}$ Docentica, Ekonomski fakultet, Sveučilište u Sarajevu, Trg oslobođenja 1, 71000 Sarajevo, Bosna i Hercegovina. Znanstveni interes: monetarna ekonomija i međunarodna ekonomija. Tel.: +38733275 941.E-mail: selena.begovic@efsa.unsa.ba (osoba za kontakt).

2 Redoviti profesor, Ekonomski fakultet, Sveučilište u Sarajevu, Trg oslobođenja 1, 71000 Sarajevo, Bosna i Hercegovina. Znanstveni interes: monetarna ekonomija, fiskalna politika $i$ međunarodna ekonomija.Tel.: +38733275 918. E-mail: sead.kreso@efsa.unsa.ba. 
Selena Begović, Sead Kreso $\bullet$ The adverse effect of real effective exchange rate change... Zb. rad. Ekon. fak. Rij. $2017 \cdot$ vol. $35 \cdot$ no. $2 \cdot 277-299$ 
Selena Begović, Sead Kreso $•$ The adverse effect of real effective exchange rate change...

Zb. rad. Ekon. fak. Rij. • $2017 \cdot$ vol. $35 \cdot$ no. $2 \cdot 277-299$

\section{Appendices}


Selena Begović, Sead Kreso • The adverse effect of real effective exchange rate change... Zb. rad. Ekon. fak. Rij. • 2017 • vol. 35 • no. 2 • 277-299 
Selena Begović, Sead Kreso • The adverse effect of real effective exchange rate change...

Table A1: The results of Equation 2 estimated by GMM for the Balkan countries (number of countries: 6)

\begin{tabular}{|c|c|c|}
\hline Variables & $\mathrm{X} / \mathrm{M}$ & $\mathrm{X} / \mathrm{M}^{*}$ Open \\
\hline \multirow[t]{2}{*}{ L.LNXM } & $0.817^{* * *}$ & \\
\hline & $(0.0125)$ & \\
\hline \multirow[t]{2}{*}{ L.LNXM_OPEN } & & $0.874^{* * * *}$ \\
\hline & & $(0.0205)$ \\
\hline \multirow[t]{2}{*}{ LNREER } & $0.0913^{* * *}$ & $0.170^{* * *}$ \\
\hline & $(0.00815)$ & $(0.0297)$ \\
\hline \multirow[t]{2}{*}{ GDPPC } & $7.05 \mathrm{e}-06^{* * *}$ & $4.25 \mathrm{e}-06$ \\
\hline & $(2.30 \mathrm{e}-06)$ & $(3.16 \mathrm{e}-06)$ \\
\hline \multirow[t]{2}{*}{ GDPG } & $0.00636^{* * *}$ & 0.0102 \\
\hline & $(0.00175)$ & $(0.00731)$ \\
\hline \multirow[t]{2}{*}{ LNTOT } & 0.113 & -0.0290 \\
\hline & $(0.0766)$ & $(0.151)$ \\
\hline \multirow[t]{2}{*}{$\mathrm{GC}$} & 0.00126 & 0.00296 \\
\hline & $(0.00101)$ & $(0.00181)$ \\
\hline \multirow[t]{2}{*}{ EU } & $0.0311^{*}$ & $0.0643^{*}$ \\
\hline & $(0.0189)$ & $(0.0381)$ \\
\hline \multirow[t]{2}{*}{ LABPRO } & $-5.97 \mathrm{e}-09$ & $-1.42 \mathrm{e}-06$ \\
\hline & $(8.33 \mathrm{e}-07)$ & $(1.47 \mathrm{e}-06)$ \\
\hline \multirow[t]{2}{*}{ FDI } & -0.000635 & -0.000716 \\
\hline & $(0.000522)$ & $(0.00195)$ \\
\hline Time dummies & included & included \\
\hline Observations & 69 & 69 \\
\hline
\end{tabular}

Note: $* * * * *, *$ donate the significance level of $1 \%, 5 \%$ and $10 \%$ respectively. Robust standard errors are reported in the parenthesis. Most of the time dummies are significant, but not presented here due to space limitations.

Source: Authors' calculations

Table A2: Diagnostic tests for the estimation of Equation 2 with GMM (Balkan countries)

\begin{tabular}{|l|rr|}
\hline \multicolumn{1}{|c}{ Dependent variable } & X/M & X/M*Open \\
\hline Number of observations & 69 & 69 \\
\hline Number of groups & 6 & 68 \\
\hline Number of instruments & 68 & $1 / 0.101$ \\
\hline Hansen/Sargan (PROB $>$ CHI2) & $1 / 0.290$ & $0.046 / 0.115$ \\
$\mathrm{~m} 1+\mathrm{m} 2$ (Pr $>\mathrm{z})$ & $0.058 / 0.444$ & \\
\hline
\end{tabular}

Source: Authors' calculations 